\title{
Research on Evaluation of Enterprise Project Culture Based on Denison Model
}

\author{
Yucheng Zeng ${ }^{1}$, Maozhu Jin ${ }^{1 *}$, Can $\mathrm{Guo}^{2}$, Zhiwei Zhang ${ }^{1}$ \\ ${ }^{1}$ Business School, Sichuan University (China) \\ ${ }^{2}$ Deyang Business Enterprise, Sichuan University (China) \\ zengyucheng@scu.edu.cn, *Corresponding author:_ïnmaozhu@scu.edu.cn, guocan1213@163.com,zzw2046@163.com
}

Received: January 2015

Accepted: June 2015

\section{Abstract:}

Purpose: The purpose of this paper is to build enterprise project culture evaluation model and search for the best evaluation method for Chinese enterprise project culture on the basis of studying and drawing lessons from enterprise culture evaluation theory and method at home and abroad.

Design/methodology/approach: Referring to the Denison enterprise culture evaluation model, this paper optimizes it according to the difference of enterprise project culture, designs the enterprise project culture evaluation model and proves the practicability of the model through empirical.

Finding: This paper finds that it's more applicable to use the Denison model for enterprise project culture evaluation through the comparative analysis of domestic and foreign enterprise culture evaluation theory and method, the systematic project culture management framework of Chinese enterprises has not yet formed through empirical research, and four factors in enterprise project culture have important influence on project operation performance improvement.

Research limitations/implications: The research on evaluation of enterprise project culture based on Denison model is a preliminary attempt, the design of evaluation index system, 
evaluation model and scale structure also need to be improved, but the thinking of this paper in this field provides a valuable reference for future research.

Practical Implications: This paper provides the support of theory and practice for evaluating the present situation of enterprise project culture construction and analyzing the advantages and disadvantages of project culture, which contributes to the "dialectical therapy" of enterprise project management, enterprise management and enterprise project culture construction.

Originality/value: The main contribution of this paper is the introduction of Denison enterprise culture model. Combining with the actual situation of enterprises, this paper also builds the evaluation model for enterprise project culture, which is helpful to promote the construction and development of Chinese enterprise project culture.

Keywords: enterprise culture, project culture, evaluation model

\section{Introduction}

In the background of the comprehensive transformation and upgrading of Chinese economic society, to adapt the demand for marketization and internationalization of the new situation, more and more Chinese enterprises transform the original enterprise management mode by introducing modern enterprise project management. "According to the survey, now $91.1 \%$ of the enterprises are adopting the Enterprise Project Management (Enterprise Project Management, EPM) model" (Zeng \& Wang, 2014). However, "project management is a systematic management idea and mode which can inevitably has great impact on the enterprises' original cultural characteristics in the process of introducing" (Li, 2010). These lead to the uncoordinated phenomenon between project management and enterprise management, this is actually "the conflict and collision of management culture or pattern." So, many enterprises gradually realized that "if they don't consider introducing the culture environment into project management, they are afraid not to succeed" (Chen, 2004). "When applying or introducing project management, enterprises should treat it as a culture rather than a management mode" (Sun, 2014). At the same time, many companies have also realized that "the core of competition among enterprises is culture" (Wang, 2014). As a result, "they should analyze the cultural differences between east and west to have a dialectical treats." This paper argues that the best way to analyze the cultural differences is just like the enterprise culture that is evaluating the culture of enterprise project, diagnosing the present situation of the project culture development, analyzing its advantages and disadvantages, and having a system cognition and rational judgment of project culture, to achieve the "dialectical treats" of project management, enterprise management and construction of project culture. 
Mainly based on literature in CNKI, this paper found that at present scholars mainly focus on the application of the enterprise project management, the researches about construction of enterprise project culture are few, and research literatures about the enterprise culture project evaluation are less. As a result, many companies do not know how to effectively evaluate their own project culture. Wang (2014) pointed out, "how to make the project culture play the biggest role for improving the brand effect and economic benefit of enterprises deserved our in-depth exploration and thinking and then find some effective and feasible ways to provide the internal motivation for the healthy development of the enterprise." This is the main problem which needs to solve urgently. How to deeply learn about the current situation of the enterprise culture construction project and find the problems existing in it and suitable assessment method for Chinese enterprise project and help to form the unique enterprise project culture, which is of great importance to "explore the problems of strengthening project cultural construction" (Gao, 2013).

This paper is on the basis of theoretical study to have a field survey and empirical research on China's enterprise project culture by using quantitative analysis method. It tries to put forward suitable model and method for enterprises to carry out project culture evaluation, providing meaningful reference for enterprise culture evaluation.

\section{Practical and Theoretical Backgrounds}

According to the enterprises they worked at, Dong (2009) think that in the process of project culture construction in some enterprises, the enterprise culture is still floating on the surface and not taking root in project department. Thus the project culture can't play a proper role. Dong also thinks that if people don't strengthen the project culture construction, the fault of enterprise culture will appear. Xie and Xu (2007) think that if the project management methods are used more widely and deeply, the impact of the cultural characteristics of the enterprise will be deeper, and the range will be wider. At the same time, project management is faced with stronger resisting strength from the corporate culture. In recent years, the studies on project culture have received a lot of attention. But there are few researches on project culture. Only Sun (2008) have done some try. Firstly, Sun summarized the studies of project culture done by national and international experts. He thinks that these studies have two features. One is that the project culture is a part of enterprise culture, it is studied based on enterprise culture. The other one is that these researches more likely belong to qualitative property, lack of quantitative evaluation of project culture achievements. Secondly, Sun also carried on exploration of evaluation of system establishment and evaluation of project culture. But his evaluation system is based on finance. It is not comprehensive and lack of some contents that can embody the project culture. And it is lack of practicability if combined with fuzzy comprehensive evaluation. 
Today, experts and scholars at home and abroad do more research on corporate culture assessment theory, and it is lack of quantitative research on assessment of project culture (Wei, 2013; Su, 2014; Chen \& Yu, 2005). But project culture is a mode of enterprise culture. As a result, we can draw lessons from the enterprise culture theory and method of evaluation for assessment of enterprise project culture.

At present, the methods of foreign corporate culture assessment commonly used include OCP constructed by Chatman, OCQ constructed by Denison, measurement scale constructed by Hofstede and OCAI by Quinn and Cameron. The domestic influential corporate culture assessment scales include VOCS scale by Zheng (1990), corporate culture assessment scale constructed by Guanghua academy of Peking University's and economics and management academy of Tsinghua University's school.

Based on the above theory and method of corporate culture assessment both at home and abroad, we can find that it is more applicable to use Denison model and scale to assess enterprise project culture. Through empirical research and case studies, Denison and Mishra construct OCQ. OCQ consists of 60 projects. Through participation, consistency, adaptability and sense of mission under the four dimensions of 12 cultural factors respectively designed five considerations of project and questionnaire to measure and reveal the content of enterprise culture (Denison \& Mishra, 1995). 1Denision Model has three prominent features. Firstly, the model and scale received recognition from the vast number of experts and scholars, it has high reliability and good practicability. Secondly, compared to the other scales, it contains more cultural factors and measuring projects, which can reflect the content of the project culture and the status more minutely and profoundly. Thirdly, the models and scales are well-operate, they can find the advantages and disadvantages of project culture construction through measurement and provide suggestions for the project team to improve project performance. Thus this paper chooses Denison model and scale as the essential theoretical foundation of the evaluation of enterprise project culture.

\section{Study Design}

Enterprise project culture evaluation model of this study was modeled with Denison culture model and OCQ scale models, and referred to the study of experts and scholars at home and abroad in the field of enterprise culture assessment, and was combined with the characteristics of Chinese culture of enterprise projects to optimize Denison culture model, such as increasing the content of project management in order to build the project evaluation model and scale which suit for Chinese enterprises and cultural. 


\subsection{Assessment Dimensions and Indicators Identified}

This paper fully considered the cultural characteristics of enterprise projects when designing enterprise culture project evaluation indicators, and it increased four aspects, including project management, project responsibilities, project internal control and project risk management. Firstly, the project risk management is the most important in enterprise project management. Enterprise risk management and control capabilities have a crucial influence on the introduction of enterprise strategy capital and stocks that were listed, and enterprise must implement a comprehensive risk management in the daily operation of the project process in order to enhance their risk management capability. Therefore, this article added the project risk management indicators to consistency dimension to evaluate the project staff's recognition and enforcement status for project risk management. Secondly, internal project control is that the enterprise project team controls the project's operational risk. Enterprises control the systemic risk and non-systematic risk in project management process through various systems to ensure that enterprise projects are mobile, safe and profitable. Therefore, this article added the internal control indicators to consistency dimension to evaluate the project staff's recognition and enforcement status for internal project control. Thirdly, project governance is that enterprise project team adjusts the project strategy and direction according to the changes of internal and external environment, and establishes project governance mechanisms to deal with the adverse effects of climate change. Therefore, this article added the project governance indicators to consistency dimension to evaluate the project staff's recognition and enforcement status for project governance. At last, project responsibility is that enterprise project team considers project objective and business goal as a starting point during the operation of the project and have a strategic vision, oppose speculation, conflict huge risk, and adhere to the road of sustainable development. Therefore, this article added the project responsibility indicators to consistency dimension to evaluate the project staff's recognition and enforcement status for project responsibility.

The model of this article eventually includes 4 dimensions, which are participation, consistency, adaptability and mission and 12 measure indicators, including project authorization, project teamwork, project human resources, project culture construction, project internal control, project risk management, project reform and innovation, project customer-oriented, project governance, project objectives vision, project core values and project responsibility. In this paper, five Likert scale score, and 1 is strongly not to agree, 2 shows a comparatively not to agree, 3 representatives it cannot be determined, 4 is more favor, 5 representatives strongly agreement. The enterprise employees who participated in the survey give an objective evaluation for each question item according to the actual situation of their enterprises and their own understanding of the project, and specific indicators are shown in Table 1. 


\begin{tabular}{|c|c|c|}
\hline Dimensions & Factors & Measuring contents \\
\hline \multirow{13}{*}{ Participation } & \multirow{4}{*}{$\begin{array}{l}\text { Project } \\
\text { authorization }\end{array}$} & $\begin{array}{l}\text { 1. The project team's decision-making is always based on adequate information } \\
\text { sharing and communication }\end{array}$ \\
\hline & & 2. When justified, I can safely make a decision acts within the scope of their duties \\
\hline & & $\begin{array}{l}\text { 3. Project staff can participate in decision-making and believe that they can have a } \\
\text { positive impact }\end{array}$ \\
\hline & & 4. Business project planning has continuity, and everyone can participate in it \\
\hline & \multirow{5}{*}{$\begin{array}{l}\text { Project } \\
\text { teamwork }\end{array}$} & $\begin{array}{l}\text { 5. The project team actively encourage cooperation between the different projects } \\
\text { within the enterprise }\end{array}$ \\
\hline & & 6. Better coordination between different levels within the project \\
\hline & & 7. Coordination of different projects is not difficult \\
\hline & & $\begin{array}{l}\text { 8. The completion of the project work is primarily through teamwork, rather than } \\
\text { hierarchical business and management }\end{array}$ \\
\hline & & 9. Project employees generally have internal teamwork spirit \\
\hline & \multirow{4}{*}{$\begin{array}{l}\text { Project } \\
\text { human } \\
\text { resources }\end{array}$} & 10. Most employees can actively work \\
\hline & & 11. Project staff can get opportunities of learning and training to improve the ability \\
\hline & & $\begin{array}{l}\text { 12. The ability of project staff is seen as a competitive advantage and an important } \\
\text { source }\end{array}$ \\
\hline & & $\begin{array}{l}\text { 13. The quality and ability of project staff have a continuous improvement under the } \\
\text { help of the project team }\end{array}$ \\
\hline \multirow{14}{*}{ Consistency } & \multirow{5}{*}{$\begin{array}{l}\text { Project } \\
\text { culture } \\
\text { construction }\end{array}$} & $\begin{array}{l}\text { 14. Project team formed a clear and consistent values to influence employees' work } \\
\text { and behavior }\end{array}$ \\
\hline & & 15. The project team has an unique management style and management methods \\
\hline & & 16. Project group attaches great importance to cultural projects and cultural activities \\
\hline & & 17. Project staff understand and agree with the corporate culture project \\
\hline & & 18. The project team has a set of standard employee behaviors \\
\hline & \multirow{5}{*}{$\begin{array}{l}\text { Project } \\
\text { internal } \\
\text { control }\end{array}$} & $\begin{array}{l}\text { 19. The related systems of projects and strategic objectives coincide with operating } \\
\text { principles }\end{array}$ \\
\hline & & 20. Project system is quite authoritative \\
\hline & & 21. Project system executes smoothly and has few exceptions \\
\hline & & 22. The design of project-related operational processes is scientific and rational \\
\hline & & $\begin{array}{l}\text { 23. The reward system of this project is unanimously approved and play an active } \\
\text { role }\end{array}$ \\
\hline & \multirow{4}{*}{$\begin{array}{l}\text { Project } \\
\text { risk } \\
\text { management }\end{array}$} & $\begin{array}{l}\text { 24. The importance of risk management within the project has been highly noticed } \\
\text { consistently }\end{array}$ \\
\hline & & $\begin{array}{l}\text { 25. Project staff agree and comply with project risk management ideas and code of } \\
\text { conduct }\end{array}$ \\
\hline & & 26. Awareness of project risk management to be fully reflected in the business \\
\hline & & $\begin{array}{l}\text { 27. The project team developed a comprehensive risk prevention and response } \\
\text { measures }\end{array}$ \\
\hline \multirow{4}{*}{ Adaptability } & \multirow{4}{*}{$\begin{array}{l}\text { Project } \\
\text { reform and } \\
\text { innovation }\end{array}$} & 28. The way of work is very flexible and easy to change \\
\hline & & $\begin{array}{l}\text { 29. The project team encourage and support innovative activities and have the } \\
\text { courage to take risks }\end{array}$ \\
\hline & & 30. Project staff continue to adopt new and advanced methods of work \\
\hline & & $\begin{array}{l}\text { 31. The project team will usually adopt or introduce some new and improved ways of } \\
\text { working }\end{array}$ \\
\hline
\end{tabular}




\begin{tabular}{|c|c|c|}
\hline Dimensions & Factors & Measuring contents \\
\hline \multirow{8}{*}{ Adaptability } & \multirow{4}{*}{$\begin{array}{l}\text { Project } \\
\text { customer- } \\
\text { oriented }\end{array}$} & $\begin{array}{l}\text { 32. Customer comments and suggestions often lead the project team do some } \\
\text { reforms and adjustments }\end{array}$ \\
\hline & & 33. Project team insisted on the idea of customer-first \\
\hline & & 34. Project staff have deep understanding of the client's wishes and needs \\
\hline & & $\begin{array}{l}\text { 35. The project team provides customers with dedicated service and always adhered } \\
\text { to the interests of customers first }\end{array}$ \\
\hline & \multirow{4}{*}{$\begin{array}{l}\text { Project } \\
\text { governance }\end{array}$} & $\begin{array}{l}\text { 36. The business strategy of the project team forces other competitors to change its } \\
\text { strategy or direction }\end{array}$ \\
\hline & & $\begin{array}{l}\text { 37. The project team understands and adapts to the changes of the various aspects } \\
\text { of the external environment }\end{array}$ \\
\hline & & $\begin{array}{l}\text { 38. The project team is good at building and improving the changes of the internal } \\
\text { and external environment }\end{array}$ \\
\hline & & $\begin{array}{l}\text { 39. The project team is good at dealing with a variety of internal and external } \\
\text { environment changes }\end{array}$ \\
\hline \multirow{14}{*}{ Mission } & \multirow{5}{*}{$\begin{array}{l}\text { Project } \\
\text { objectives } \\
\text { vision }\end{array}$} & 40. The project team developed a long-term goals and strategic direction \\
\hline & & 41. Objective vision of the project team gets consensus unanimously \\
\hline & & 42. Objective vision of the project team provides guidance and generate incentives \\
\hline & & 43. Project managers have long-term vision and focus on the growth of staff \\
\hline & & $\begin{array}{l}\text { 44. Keep track of the achievement of stated objectives and constantly strive to go } \\
\text { ahead }\end{array}$ \\
\hline & \multirow{4}{*}{$\begin{array}{l}\text { Project core } \\
\text { values }\end{array}$} & 45. The project team has a clear purpose and idea \\
\hline & & 46. Project managers can strictly guide practice according to the project purpose \\
\hline & & $\begin{array}{l}\text { 47. Project staff can understand the project purpose and apply to the actual project } \\
\text { work }\end{array}$ \\
\hline & & $\begin{array}{l}\text { 48. Project aims are moral standards that measure the right and wrong behaviors of } \\
\text { the project staff }\end{array}$ \\
\hline & \multirow{5}{*}{$\begin{array}{l}\text { Project } \\
\text { responsibility }\end{array}$} & $\begin{array}{l}\text { 49. Project team adheres to the "people-oriented", and the road of sustainable } \\
\text { development }\end{array}$ \\
\hline & & 50. The project team take achieving their overall strategic goals as their mission \\
\hline & & $\begin{array}{l}\text { 51. The project team developed an objective vision coinciding with the overall goal of } \\
\text { enterprise }\end{array}$ \\
\hline & & $\begin{array}{l}\text { 52. Projects maintain that the internal and external environment develops } \\
\text { harmoniously in the process of operation }\end{array}$ \\
\hline & & 53. Project managers have long-term vision and oppose speculation and huge risks \\
\hline
\end{tabular}

Table 1. Enterprise Cultural Assessment Scale Project

\subsection{Sample Data Collection}

The survey objectives are from different enterprises employees of Sichuan, Yunnan, Chongqing, Hunan, Shenzhen and Zhejiang, etc., and these enterprises covers eastern, central and western of China, and these companies have regional and local characteristics to ensure the reliability and validity of the sample data. The 240 survey questionnaires were returned 180 , excluding 43 invalid questionnaires whose option has the obvious regularity or the data is 
imperfect and conflicting, and 137 valid questionnaires were recovered, and the effective response rate is $57.08 \%$. Sample constituting is shown in Table 2.

\begin{tabular}{|c|c|c|c|}
\hline & Classification & Number & Percentage (\%) \\
\hline \multirow{2}{*}{ Sex } & Male & 52 & $37.96 \%$ \\
\hline & Female & 85 & $62.04 \%$ \\
\hline \multirow{4}{*}{ Age } & Below 30 years old & 106 & $77.37 \%$ \\
\hline & $30 \sim 39$ & 20 & $14.6 \%$ \\
\hline & $40 \sim 49$ & 7 & $5.11 \%$ \\
\hline & Above 50 years old & 4 & $2.92 \%$ \\
\hline \multirow{3}{*}{ Educational background } & College and below & 4 & $2.92 \%$ \\
\hline & Bachelor (including double degree) & 81 & $59.12 \%$ \\
\hline & Master and above & 52 & $37.96 \%$ \\
\hline \multirow{5}{*}{ Time to join the enterprises } & Less than 1 year & 36 & $26.28 \%$ \\
\hline & $1 \sim 3$ years & 45 & $32.85 \%$ \\
\hline & $3 \sim 5$ years & 32 & $23.36 \%$ \\
\hline & $5 \sim 10$ years & 13 & $9.49 \%$ \\
\hline & More than 10 years & 11 & $8.03 \%$ \\
\hline \multirow{4}{*}{ Title } & Employees & 100 & $72.99 \%$ \\
\hline & Head of Department & 21 & $15.33 \%$ \\
\hline & $\begin{array}{c}\text { Vice manager/ } \\
\text { Dept. vice manager }\end{array}$ & 9 & $6.57 \%$ \\
\hline & Manager/Dept. Manager & 7 & $5.11 \%$ \\
\hline
\end{tabular}

Table 2. Samples Overview

\subsection{Data Analysis}

\subsubsection{Reliability Analysis}

Reliability analysis is mainly used to analyzing the reliability of the scale of the questionnaire. This paper took Cranach Alpha for reliability analysis in

SPSS19.0. Cronbach Alpha is used to computing consistency reliability, many experts believe that the higher the reliability coefficient is, the better the reliability scale is. And when reliability coefficients above 0.8 , it means that reliability is very good. When reliability coefficient is within the range of 0.7 to 0.8 , it is acceptable and when below 0.7 , the scale should be revised and new test should be done (Bagozzi \& Yi, 1988). 
It can be seen from Table 3, the Cronbach Alpha values of various dimensions and their following factors are all above 0.7 , indicating all dimensions and factors could well reflect the content of the project culture and high reliability for all indicators.

\begin{tabular}{|l|c|}
\hline \multicolumn{1}{|c|}{ Dimensions and factors } & Has been deleted Cronbach's Alpha value \\
\hline Participation dimension of the total table & 0.931 \\
\hline Project authorization reliability factor analysis & .777 \\
\hline Project teamwork reliability factor analysis & .824 \\
\hline Project human resource reliability factor analysis & .842 \\
\hline Consistency dimension of the total table & 0.933 \\
\hline Project culture construction reliability factor analysis & .868 \\
\hline Project internal control reliability factor analysis & .867 \\
\hline Project risk management reliability factor analysis & .844 \\
\hline Adaptability dimension of the total table & 0.930 \\
\hline Project reform and innovation reliability factor analysis & .851 \\
\hline Project customer-oriented reliability factor analysis & .851 \\
\hline Project governance reliability factor analysis & .845 \\
\hline Mission dimension of the total table & 0.935 \\
\hline Project objectives vision reliability factor analysis & .852 \\
\hline Project core values reliability factor analysis & .833 \\
\hline Project responsibility reliability factor analysis & .883 \\
\hline
\end{tabular}

Table 3. Project cultural evaluation dimensions and Cronbach Alpha coefficient of factor

\subsubsection{Validity Analysis}

Validity Analysis is used to test the degree that the scale questionnaire can accurately measure the required factors and characteristics (Wu, 2003). In this paper, we measured the validity by factor analysis. Before factor analysis, we generally use Bartlett Test of Sphericity and KaiserMeyer-Olkin to evaluate whether the scale questionnaire is suitable for factor analysis or not. Based on previous studies, when Bartlett value is comparatively large, and the corresponding probability value $P$ is less than a given significance level, the correlation between the variables is relatively good, the variables are suitable for factor analysis; On the contrary, they are not suitable. For KMO test, the value is more close to 1 , the higher correlation they have, and they are suitable for factor analysis; on the contrary, they are not suitable. Generally speaking, when KMO test value is above 0.6 , and factor load coefficients for all projects are greater than 0.5 , it can be analyzed by using factor analysis method.

As is shown from Table 4, KMO value of each dimension is very close to 1 , this indicates that they have more common elements among the variables, and it is suitable for factor analysis; 
Bartlett value of each dimension is large and significant probability $P$ is 0.000 which is less than 0.001 . This indicates that the items are relevant, there are common factors, and they are suitable for factor analysis.

\begin{tabular}{|c|c|c|c|c|}
\hline \multirow{2}{*}{ Dimensions } & $\begin{array}{c}\text { The KMO and Bartlett's test } \\
\text { Sampling sufficient } \\
\text { degree of Kaiser-Meyer- } \\
\text { Olkin measure }\end{array}$ & \multicolumn{2}{|c|}{ Bartlett Test of Sphericity } \\
\cline { 3 - 5 } & .913 & 1178.114 & 78 & .000 \\
\hline Participation dimension & .904 & 1257.500 & 91 & .000 \\
\hline Conformed dimension & .905 & 1187.338 & 66 & .000 \\
\hline Adaptability dimension & .921 & 1319.425 & 91 & .000 \\
\hline The sense of mission dimension & Chigred approximation & 9 \\
\hline
\end{tabular}

Table 4. The dimensions of KMO and Bartlett's test

By extracting common factors from participatory dimensions of each index factor, the results show that we can choose three factors on the basis that the eigenvalues should be greater than 1. The load factors of three factors are all greater than 0.5. They are in line with the extracted requirements. The former 5 indexes are categorized as factor 1 to reflect the team cooperation. The middle 4 indexes are categorized as factor 2 to reflect the content of human resources. The last 4 indexes are classified as factor 3 to reflect the content of authorization. Through factor analysis, participatory dimension is divided into three sub-dimensions. As shown in Table 5.

\begin{tabular}{|l|c|c|c|}
\hline \multirow{2}{*}{} & \multicolumn{3}{|c|}{ Rotated Component Matrix } \\
\cline { 2 - 4 } & \multicolumn{2}{|c|}{ Component } \\
\hline The project team cooperation (8) & .830 & .129 & .135 \\
\hline The project team cooperation (7) & .814 & .328 & .209 \\
\hline The project team cooperation (6) & .752 & .284 & .335 \\
\hline The project team cooperation (10) & .742 & .247 & .240 \\
\hline The project team cooperation (9) & .646 & .269 & .405 \\
\hline The project human resource (11) & .265 & .834 & .139 \\
\hline The project human resource (14) & .165 & .740 & .228 \\
\hline The project human resource (13) & .310 & .732 & .366 \\
\hline The project human resource (15) & .271 & .347 \\
\hline The project authorization (2) & .215 & .308 & .848 \\
\hline The project authorization (1) & .191 & .301 & .812 \\
\hline The project authorization (4) & .306 & .729 \\
\hline The project authorization (5) & .436 & .603 \\
\hline
\end{tabular}

Extraction Method: Principal Component. Rotation Method: a Kaiser standardized varimax.

Table 5. Factor analysis of participation dimension 
By extracting common factors from conformed dimension of each index, the results show that we can choose three factors on the basis that the eigenvalues should be greater than 1 . The load factors of three factors are all greater than 0.5 . They are in line with the extracted requirements. The former 5 indexes are categorized as factor 1 to reflect the contents of the internal control. The middle 5 indexes are categorized as factor 2 to reflect the content of the cultural construction. The last 4 indexes are classified as factor 3 to reflect the content of risk management. Through factor analysis, participatory dimension is divided into three sub-dimensions. As shown in Table 6.

\begin{tabular}{|l|c|c|c|}
\hline \multirow{2}{*}{} & \multicolumn{3}{|c|}{ Rotated Component Matrix } \\
\cline { 2 - 4 } & 1 & 2 & 3 \\
\hline The project internal control (9) & .826 & .117 & .301 \\
\hline The project internal control (10) & .825 & .331 & .287 \\
\hline The project internal control (7) & .771 & .282 & .326 \\
\hline The project internal control (8) & .725 & .393 & .351 \\
\hline The project internal control (6) & .679 & .305 & .298 \\
\hline The project cultural construction (2) & .214 & .799 & .176 \\
\hline The project cultural construction (4) & .343 & .760 & .305 \\
\hline The project cultural construction (3) & .164 & .613 & .190 \\
\hline The project cultural construction (1) & .371 & .531 & .417 \\
\hline The project cultural construction (5) & .322 & .277 & .815 \\
\hline The project risk management (13) & .190 & .218 & .784 \\
\hline The project risk management (12) & .253 & .194 & .690 \\
\hline The project risk management (11) & .415 & .270 & .685 \\
\hline The project risk management (14) & .123 & \\
\hline
\end{tabular}

Extraction Method: Principal Component. Rotation Method: a Kaiser standardized varimax.

Table 6. Factor analysis of conformed dimension

After factor analysis of adaptability dimension of each index is done, the results show that we can choose three factors on the basis that the eigenvalues should be greater than 1 . The load coefficients of three factors are all greater than 0.5 . They are in line with the extracted requirements. The former 4 indexes are categorized as factor 1 to reflect the contents of project reform and innovation. The middle 4 indexes are categorized as factor 2 to reflect the content of project governance. The last 4 indexes are classified as factor 3 to reflect the content of project customer oriented. Through factor analysis, participatory dimension is divided into three sub-dimensions. As shown in Table 7. 


\begin{tabular}{|l|c|c|c|}
\hline \multicolumn{1}{|c|}{ Rotated Component Matrix } \\
\cline { 2 - 4 } & \multicolumn{2}{|c|}{ Component } \\
\cline { 2 - 4 } & 1 & 2 & .195 \\
\hline The project reform and innovation (2) & .850 & .294 & .310 \\
\hline The project reform and innovation (3) & .816 & .260 & .290 \\
\hline The project reform and innovation (1) & .805 & .281 & .193 \\
\hline The project governance (12) & .746 & .772 & .226 \\
\hline The project governance (11) & .293 & .754 & .262 \\
\hline The project governance (13) & .160 & .734 & .348 \\
\hline The project governance 14) & .338 & .148 & .843 \\
\hline The project customer oriented (7) & .223 & .254 & .822 \\
\hline The project customer oriented (10) & .303 & .330 & .696 \\
\hline The project customer oriented (6) & .142 & .476 & .573 \\
\hline The project customer oriented (8) & .414 & .447 & \\
\hline
\end{tabular}

Extraction Method: Principal Component. Rotation Method: a Kaiser standardized varimax.

Table 7. Factor analysis of adaptability dimension

By extracting common factors from the sense of mission dimension of each index, the results show that we can choose three factors on the basis that the eigenvalues should be greater than 1 . The load coefficients of three factors are all greater than 0.5. They are in line with the extracted requirements. The former 5 indexes are categorized as factor 1 to reflect the contents of project objective vision. The middle 4 indexes are categorized as factor 2 to reflect the content of project responsibility. The last 4 indexes are classified as factor 3 to reflect the content of project core values. Through factor analysis, participatory dimension is divided into three sub-dimensions. As shown in Table 8. 


\begin{tabular}{|c|c|c|c|}
\hline \multicolumn{4}{|c|}{ Rotated Component Matrix } \\
\hline & \multicolumn{3}{|c|}{ Component } \\
\hline & 1 & 2 & 3 \\
\hline The project objective vision (1) & .812 & & .179 \\
\hline The project objective vision (2) & .776 & .319 & .225 \\
\hline The project objective vision (4) & .747 & .242 & .147 \\
\hline The project objective vision (3) & .746 & .259 & .304 \\
\hline The project objective vision (5) & .718 & .282 & .344 \\
\hline The project responsibility (12) & & .846 & .309 \\
\hline The project responsibility (13) & .214 & .764 & .379 \\
\hline The project responsibility (15) & .360 & .758 & .107 \\
\hline The project responsibility (11) & .392 & .615 & .348 \\
\hline The project responsibility (14) & .443 & .609 & .197 \\
\hline The project core values (6) & .410 & .189 & .789 \\
\hline The project core values (9) & & .284 & .775 \\
\hline The project core values ( 8 ) & .288 & .378 & .734 \\
\hline The project core values (7) & .426 & .219 & .732 \\
\hline
\end{tabular}

Extraction Method: Principal Component. Rotation Method: a Kaiser standardized varimax.

Table 8. Factor analysis of the sense of mission dimension

\subsubsection{Correlation Analysis}

This article studied the correlation between project operation performance and 12 factors under 4 dimensions in Chinese enterprises project cultural evaluation model. Before regression analysis, we use Pearson product-moment correlation coefficient $r(-1 \leq r \leq 1)$ to analyze the relationship between the independent variables and the dependent variable. The greater the absolute value of $r$ is, the higher correlation between variables is. $r=0$ indicates there is no correlation; $0<r \leq 1$ indicates there is a positive correlation, $-1 \leq r<0$ indicates there is a negative correlation. According to Table 9, we can conclude that 12 factors under four dimensions are related to enterprises project operation performance, but $r$ of project cultural construction is $\mathbf{0 . 7 5}$, then this factor should be removed before regression analysis, otherwise it will produce relatively large deviations; the correlation of project authorization, project risk management and project responsibilities is less than 0.5 , which indicates that the correlation of project operation performance is lower than other factors'. 


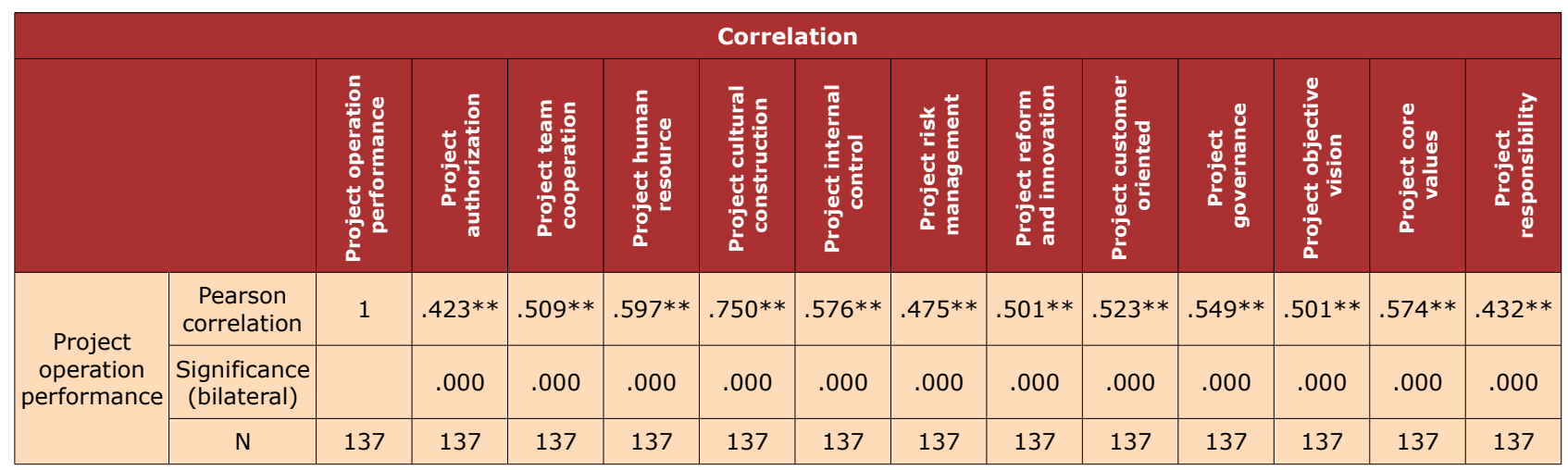

**. Significant correlation at .01 level (bilateral).

Table 9. Correlation analysis among the variables

\subsubsection{Regression Analysis}

According to the data results of Pearson analysis, this paper will continue to conduct regression between the factor of enterprise project operational performance and 12 other factors under participation, consistency, adaptability and 4 dimensions of sense of mission, which need to do 4 regression model analyses, to verify whether there is a significant correlation between that 12 factors and enterprise project operational performance.

According to each dimension and factor of regression model parameter from the Table 10, project authorization of participation dimension is not significant, and should be eliminated; the project team collaboration and project human resources are significant, which indicates that these two factors can well reflect the project operational performance. In consistency dimension the project internal control and project risk management are significant, which indicates that these two factors can well reflect the project operational performance. In adaptability dimension the project reform innovation is lowly significant, the customer-oriented of project and project governance are significant, these three factors can basically reflect the project operational performance. In sense of mission dimension the project responsibility is not significant, and should be eliminated; the project objective vision and project core values are significant, these two factors can reflect the project operational performance well. 


\begin{tabular}{|c|c|c|c|c|c|c|c|c|}
\hline \multicolumn{9}{|c|}{ Coefficient a } \\
\hline & \multirow{2}{*}{ Model } & \multicolumn{2}{|c|}{$\begin{array}{l}\text { Non-standardized } \\
\text { coefficients }\end{array}$} & \multirow{2}{*}{$\begin{array}{c}\begin{array}{c}\text { Standardized } \\
\text { coefficients }\end{array} \\
\text { Trial version }\end{array}$} & \multirow{2}{*}{$\mathbf{t}$} & \multirow{2}{*}{ Sig. } & \multicolumn{2}{|c|}{$\begin{array}{l}\text { Collinearity } \\
\text { statistics }\end{array}$} \\
\hline & & B & $\begin{array}{l}\text { Standard } \\
\text { error }\end{array}$ & & & & Tolerance & VIF \\
\hline \multirow{4}{*}{$\begin{array}{l}\text { Participation } \\
\text { dimension }\end{array}$} & (Constant) & .885 & .320 & & 2.767 & .006 & & \\
\hline & Project authorization & -.007 & .026 & -.027 & -.280 & .780 & .487 & 2.055 \\
\hline & $\begin{array}{l}\text { Project team } \\
\text { collaboration }\end{array}$ & .049 & .020 & .237 & 2.465 & .015 & .496 & 2.017 \\
\hline & Project human resources & .132 & .026 & .467 & 5.025 & .000 & .531 & 1.881 \\
\hline \multirow{3}{*}{$\begin{array}{l}\text { Consistency } \\
\text { dimension }\end{array}$} & (Constant) & 1.036 & .337 & & 3.072 & .003 & & \\
\hline & Project internal control & .098 & .019 & .457 & 5.144 & .000 & .610 & 1.638 \\
\hline & Project risk management & .056 & .026 & .190 & 2.131 & .035 & .610 & 1.638 \\
\hline \multirow{4}{*}{$\begin{array}{l}\text { Adaptability } \\
\text { dimension }\end{array}$} & (Constant) & 1.084 & .307 & & 3.531 & .001 & & \\
\hline & Project reform innovation & .043 & .025 & .171 & 1.738 & .085 & .492 & 2.033 \\
\hline & $\begin{array}{l}\text { Project customer } \\
\text { oriented }\end{array}$ & .050 & .025 & .205 & 2.000 & .048 & .454 & 2.202 \\
\hline & Project governance & .087 & .027 & .309 & 3.199 & .002 & .514 & 1.947 \\
\hline \multirow{4}{*}{$\begin{array}{l}\text { Sense of } \\
\text { mission } \\
\text { dimension }\end{array}$} & (Constant) & .859 & .344 & & 2.498 & .014 & & \\
\hline & Project objective vision & .053 & .023 & .228 & 2.346 & .020 & .510 & 1.959 \\
\hline & Project core values & .119 & .028 & .433 & 4.283 & .000 & .470 & 2.128 \\
\hline & Project responsibility & -.002 & .021 & -.007 & -.072 & .942 & .469 & 2.133 \\
\hline
\end{tabular}

a. Dependent variable: project operational performance

Table 10. Each Dimension and Factor Regression Model Parameter Table

\section{Research Summaries}

This paper teases and refers to the domestic and international project cultural theories and project cultural evaluation study theories, and through the empirical study of Chinese enterprises, proposes the Chinese enterprise project cultural evaluation model. This model has a certain reference value for measuring, analyzing, and assessing the status of Chinese enterprise project culture construction, cultural strengths and weaknesses and other related issues. This research mainly has the following several innovations:

1. This paper establishes the evaluation model of Chinese enterprise project culture. At present the researches on enterprise project management mainly focus on the study of the application of project management, less on the aspects of project cultural evaluation. Based on the Denison enterprise culture trait model, this paper evaluates the enterprise project culture from 4 dimensions which includes the participation, consistency, continuity, and sense of mission. And each dimension corresponds to three cultural factors. The project risk culture, project internal control culture and project innovation culture etc. of the enterprise project culture are particular highlighted among these 12 factors, so the Chinese enterprise project culture evaluation model has practical guidance and reference function. 
2. This paper develops the scale that is suitable for Chinese enterprise project culture evaluation. Referring to the research results of experts and scholars of OCQ scale and combining with the actual situation of Chinese enterprises, this paper deeply studies the enterprise project cultural features, connotation etc. it teases out 12 factors in the light of Chinese enterprise project cultural particularity, and forms the scale that is suitable for Chinese enterprise project culture evaluation, which will provide a new tool for Chinese enterprise project culture construction.

3. This paper conducts the empirical study of Chinese enterprise project culture evaluation. The model and scale is used to evaluate the current situation of Chinese enterprise culture construction, and it shows that the model and scale in the evaluation of Chinese enterprise project culture is effective and feasible through the empirical study. The evaluation study found that Chinese enterprises in the aspect of project culture construction need to be further improved and perfected. Meanwhile, several factors of enterprise project culture have important influence on the enhancement of project operational performance. Therefore, dynamic enterprise project culture evaluation has a pivotal role of enhancing project culture and enterprise culture core competitiveness of Chinese enterprises.

4. This paper provides a new theory and method for enterprise project culture construction. Enterprise project management is a new management mode of enterprise management. So, the enterprise project culture construction is the weak link of enterprise culture construction. The research of this paper will provide a new thought and method for the enterprise project culture construction to promote the enterprise project culture construction and improve the enterprise culture construction.

Studies have shown that enterprise project culture is the source to gain enterprise core competitiveness through projects. It can effectively meet the requirements of marketization and internationalization of new situation. Only the construction of unique project culture could carry out the dislocation competition among enterprises, and ensures the healthy and sustainable development of enterprise. Therefore, if Chinese enterprises want to improve their own competitiveness in the fierce competition in the future, they must attach much importance to the construction of enterprise project culture.

Although this paper has made some progress and results in the aspect of Chinese enterprise project culture evaluation, it still has some limitation, mainly the following three aspects:

1. From the perspective of research object, this paper studies the Chinese enterprise project culture evaluation model and scale. However, only a few experts both at home and abroad study enterprise project culture evaluation, and the references are less, so this enterprise project culture evaluation based on Denison enterprise model is a 
preliminary attempt, and how to choose project culture evaluation indicators for Chinese enterprises remains to be further studied and improved.

2. From the perspective of sample selection, due to the constraints of region, time, money and many other conditions, the main objects participated in the evaluation are enterprise employees of Sichuan, Yunnan, Chongqing, Hunan, Shenzhen and Zhejiang in carrying out the evaluation questionnaire, so the coverage is not very wide. Meanwhile, the number of effective samples was 137 copies, the limited sample size will also have some impact on the precision of the results of statistical analysis.

3. From the perspective of model scale, in the design of Chinese enterprise project culture evaluation model scale, this paper mainly adopted the method of literature review and qualitative analysis to amend and perfect the existing and more mature model scale, so it is hard to avoid some problems existing in the construction of the structure of model scale, this also needs to be improved.

Aiming at the above deficiency and limitation, it is good to improve and perfect the following aspects in future studies:

1. This paper did not conduct the expanding in-depth research and analysis on the impact of 12 factors of enterprise project culture on the project operational performance. So we can divide the enterprise project operation performance indicators into multiple evaluation factors in future studies, and further explore the relevance of enterprise project culture factors and each factor of project operational performance, and provide guidance for improving enterprise project culture construction and project operational performance.

2. On the choice of the index system, evaluation model and specific scale, the main reference is Denison enterprise culture trait model in this paper. This model contains abundant dimensions and indicators, which is able to present more comprehensive evaluation of enterprise project culture. However, this model also has its limitations. We can design more targeted model scale to develop project culture measurement, diagnosis and evaluation later.

3. Future studies should combine the qualitative and quantitative research, theoretical and empirical research organically. Meanwhile, it needs to integrate the advantages of different research methods, ideas and perspectives. This can not only enrich the theory of the field of enterprise project culture evaluation, but also enhance the practicability. 


\section{Acknowledgements}

The authors wish to thank the Major International Joint Research Program of the National Natural Science Foundation of China (Grant No. 71020107027), the National Natural Science Foundation of China (Grant No. 71001075), Central University Fund of Sichuan University with No.skqy201409 under which the present work was possible.

\section{References}

Bagozzi, P.R., \& Yi, Y. (1988). On the evaluation of structural equation models. Journal of the Academy of Marketing Science, 16, 74-94. http://dx.doi.org/10.1007/BF02723327

Chen, C., \& Yu, J. (2005). The cooperative relationship in the project construction. Enterprise Economy, 4, 61-62.

Chen, Y. (2004). Cultural interpretation of project management. China Engineering Consulting, 2(42), 18-19.

Denison, D.R., \& Mishra, A.K. (1995). Toward a theory of organizational culture and effectiveness. Organization Science, 6(2), 204-223. http://dx.doi.org/10.1287/orsc.6.2.204

Dong, H. (2009). From "blood transfusion" to "blood"-the effective way to construct project culture of construction enterprise. Construction Enterprise Management, 3(247), 70-81.

Gao, J. (2013). Research on the improvement of project management level based on strengthening the project culture construction. Oriental Enterprise Culture, 1, 81-82.

$\mathrm{Li}, \mathrm{X}$. (2010). The effect of project management to the enterprise culture and project culture analysis. Commercial Economy, 8, 93-95.

Su, X. (2014). Discussion on how to increase the project culture construction effectively. Oriental Enterprise Culture, 14, 102.

Sun, J. (2014). Project culture construction under new situation. Oriental Enterprise Culture, 3, 135.

Sun, X. (2008). Project culture evaluation system construction and evaluation model. Abstract Management Science, 3, 266-268.

Wang, H. (2014). Thoughts on the culture construction of construction enterprise project. Chinese and Foreign Entrepreneurs, 7(465), 214-215. 
Wei, J. (2013). Primary discussion on the role of culture project in the enterprise development in new period. China Management Informatization, 2, 69-70.

Wu, M. (2003). SPSS statistics application practice-questionnaire analysis and applied statistics. Beijing: Science Press.

Xie, G., \& Xu, J. (2007). Analysis of enterprise culture characteristics and project culture based on project management. Economic Theory Research, 1, 40-43.

Zeng, Y., \& Wang, J. (2014). Research on the coupling of enterprise strategy management and project management. Journal of Sichuan University, 3(192), 86-96.

Zheng, B. (1990). Quantitative assessment of enterprise culture values. Chinese Journal of Psychology, 32.

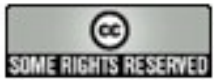

Article's contents are provided on a Attribution-Non Commercial 3.0 Creative commons license. Readers are allowed to copy, distribute and communicate article's contents, provided the author's and Journal of Industrial Engineering and Management's names are included. It must not be used for commercial purposes. To see the complete license contents, please visit http://creativecommons.org/licenses/by-nc/3.0/. 